\title{
Intellectuals and Society
}

If one conceives of modern society as a society that strives to free itself from the hand of tradition and conventional wisdom, then it seems difficult to overestimate the role of the intellectuals. Undoubtedly, the concept of the intellectual. Its an ambiguous one. Its elusive character becomes apparent even from a linguistic point of view: the term intellectual is both a substantive and an adjective. Functionally speaking, one could perhaps define the intellectual as a person that uses professionally his or her own intellect. As such, it is hard to believe, as some authoritative scholars have maintained (dr. Wolf Lepenies among others), that the figure of the intellectual emerges historically at the end of the XIX century in France with Emile Zola and his famous article in the paper Aurore, entitled "J'accuse in defense" of Charles Dreyfus, as a case destined to shaken the third French Republic lining up the militarist and antiSemitic right wing against the progressive political and cultural groups.

A different view can be positively argued. The emergence of the intellectual as a relatively free social agent can plausibly be placed at the very beginning of modern society as a society based on rational calculation and planning its driving concept of progress as a task and as an inevitable goal for humanity as a whole at the same time was expounded and publicize by intellectuals. While waiting for the Terror Guards in order to be accompanied to the guillotine and executed, Condorcet had just finished his admirable Esquisse du progrés de l'esprit humain in which ten great "epochs" are distinguished and duly described from the nomadic pastoral peoples, slowly turning into sedentary farmers and soil tillers, to the industrial nations, relatively "rational", until the "invention of the printing press when the sciences together with philosophy were able to shake off the weight of authority" ("invention de l'imprimerie jusqu'aux temps ou les sciences et la philosophie secouerent le joug de l'autorite"). In the final "epoch", the tenth one, according to Condorcet, we will finally find the mature progress of mankind, an age in which one can enjoy "the true reward of virtue, the pleasure of having accomplished a lasting good that fatality will not be able to destroy for some sort of tragic countermeasure getting us back to prejudice and slavery", (Ia vrai recompense de la vertu, le plaisir d'avoir fait un bien durable, c'est que la fatalité ne detruira plus par une compensation funeste, en ramenant les prejugés et l'esclavage).

Needless to say, Condorcet had been anticipated by the pioneers of free thinking from Copernicus, Giordano Bruno, Descartes to Galileo, Newton, Spinoza, not to mention the philosophers and the Encyclopédie, led by Diderot and d'Alembert. Also the enthusiastic forerunners of the great revolution of 1789 , from Voltaire to Rousseau, despite the precise strictures of Edmund Burke in his Reflections on the Revolution in France, should be mentioned in this connection. 
Progress, however, is not a chronological fatality. It is true that the myth of progress as elaborated by the progressive intellectuals has profound roots in the European and American culture. But progress is essentially a problematic concept. No progress can be taken for granted against failure and final bankruptcy. The Faustian dream, directly connected with the mythological promethean attempt, entertains nevertheless a genuine fascination for Western Culture. Even a contemporary sociologist as authoritative as Talcott Parsons feels he can define in general terms the culture of the United States as "instrumental activism". Progress is conceived as absolutely guaranteed, but only science, revered as a secular religion with the intellectuals as lay priests, will be able to assure its orderly development and its coherent implementation on the historical level. No transcendent justification is deemed necessary. The theory of progress, with science as the key and decisive instrument of happiness or bonheur of mankind, opens a new way to worldly salvation. Humanity seems to be coming of age and to accept Kant's admonition: "Sapere aude" (Dare to know).

For these reasons, it does not seem tenable to consider Emile Zola as the first intellectual. In fact, in the historical perspective, the intellectual comes from far away, perhaps as far as the year one thousand, passing through at least three major phases:

a) what I like to call the "levitic phase", when he is at the service of the popes and the Church, handles the sacred texts, interprets the Holy Scriptures, and writes eventually the encyclical papal letters, naturally under the strict supervision of his superiors;

b) the phase of the court jester, engaged in relieving the boredom of the king and among the courtiers, but he is also a legal specialist in the royal service, in constant conflict with his clerical counterpart following the changing power relationship between pope and emperor;

c) the phase of the "industrial revolution", when finally, with a free market and a relative increase in scholarly professions, the intellectual can reasonably try to get his means of subsistence in an autonomous way. In this respect, authors such as Bertrand de Jouvenel and Ludwig von Mises (especially in his Anticapitalistic Mind) do not spare the intellectuals a host of very harsh criticism because they see in them an unconscious nostalgia for the quiet life of the convent, for a quietum servitium, in which the clerical intellectual used to be sheltered and protected against the unpredictable fluctuations of the open market.

Among present day scholars, two eminent and well-known American sociologists, Talcott Parsons and Edward A Shils, perhaps in a self-gratifying mood, have defined the intellectual as a person having a special access to the sacred, that is to the higher non utilitarian values. As such, the intellectual is, in their view, both the creator and the gate-keeper, as it were, of the "noble ideas" that are not connected or tainted by commercial intent. This angelical conception of the intellectual cannot claim to be 
very original. In fact, it is not too far from the one presented in Ideology and Utopia, by Karl Mannheim, who, in blatant contradiction with his own theory concerning the social conditioning of thought, would see the intellectuals, although naturally born in certain families and special classes, as able to go beyond cultural prejudices and ethnocentric local idiocy to achieve a high degree of objectivity by freely flying over (freischweben) specific contrasting class interests.

Analogous arguments in favor of the intellectuals, curiously fluctuating between a defense of the corporation and a nostalgia for the monastery, can be found in the passionate lecture by Max Weber on "Wissenschaft als Beruf(Science as a Profession or, perhaps more precisely, as a Vocation). In Weber's view, in the term of "Werfreiheit" or "freedom from values", a definite distinction should be made between ethical options or principles of purely personal preference and objective determinations, supposed to be intersubjectively binding. However, in Weber himself the distinction between "erklären" or "clarifying" and "verstehen", or "understanding" and "explaining", remains essentially vague and the most one can hope for in trying to perceive and interpret social reality amounts to a "disciplined subjectivity".

In this connection, it has been aptly remarked that "Weber's critique of the technocratic elites professing to have reduced questions of socio-economic policy to a "science" overlaps his basic antipathy to the ideologies of intellectuals (...) Weber's neo-Kantian epistemology and his polytheistic social ontology exclude logical ratiocination as a means of solving socio-economic and ultimately political problems. On this basis, Weber argued that what purported to be the newly discovered "laws" of economics could arrive at unambiguous "social policies" only at the expense of treating a number of their presuppositions as self- evident. (...) Weber was aware of and warned against the spurious "self-evidence" of ideal types. The laws of economics, being nothing but another set of ideal types, might also give the appearance of self-evidence. This is why Weber preferred that the questions of social policy be "disputed" publicly rather than "solved" as technical problems" enterprise has been recently leveled by Hilton Kramer'. In a culture as imbued with anti-intellectualism as the American one, it seems that Kramer's strictures are hardly necessary. In the United States the great admiration of the informed public usually does not go to the thinker, but to the doer. Choosing an intellectual pursuit as a life project is still considered typical of a person who feels defeated, a professional failure.

The main flaw of Kramer's analysis, however, lies in the fact that he regards the intellectual as a leftist by definition, at least in the sense that the intellectual suffers from an inferiority complex, if not a guilt feeling that make him or her irrationally prone to favour any kind of socialist or communist utopia. This does not seem to be

\footnotetext{
${ }^{1}$ Cfr. Ahmed Sadri, Maw Weber's Sociology of intellectuals, Oxford University Press, New York, 1992, pag. 88.

${ }^{2}$ Cfr. Hilton Cramer, The Twilight of the intellectuals, Ivan R, Dee, New York 1999
} 
the case. It is true that, as remarked by Samuel N. Eistenstadt, those who have been concerned with cultural issues from a conservative point of view have rarely, if ever, been considered "intellectuals". But, what about those former left wing intellectuals who have in recent years become moderate and even reactionary? It is not only the case, for an instance, of Norman Podhorez in the United States, but also of persons such as André Malraux in France, from radical left to Gaullism, or Lucio Colletti, in Italy, from militant Marxism to extreme right wing member of Parliament.

The fact is that the traditional intellectual, whether leftist or moderate in his or her political views, appears to be, first of all, interested in himself or in herself, according to a tangentially narcissistic attitude that makes for an essentially a-social disposition. Whether ready to climb the barricades for a total revolution, here and now, or confined in the ivory tower in thoughtful solitude, the traditional intellectual shows the same neglect, if non contempt, for the everyday needs of the masses that he or she proclaims at the center of his or her interest.

In a modern technically advanced society, the role of the intellectual becomes more complicated. It is neither the vocal proposition of an instant revolution nor the stubborn defense of the existing social and political situation. Under present day circumstances, the intellectual who does not confine himself to the role of a mere technician, must be in the end a careful, "scientific" demistifyer. His or her contribution in unmasking social and political power is of decisive importance. Advanced societies at present are usually defined as "information" societies. Information is a paradoxical item that you can steal without removing it. What does this mean from a practical point of view? Information is certainly necessary, but is it sufficient?

Information, deformation, transformation: where are we? Where do we go from here? Who is informing? Who gets informed: for whom, against whom? For what? Against what?

These are some of the fundamental questions that make up the substance of the intellectual in a modern society. Understandably enough, the tackling of such issues might be regarded as futile or as a useless exercise on idle curiosity in a cultural environment in which division of labor and specialization of professional tasks are largely given an almost absolute priority. In this kind of society the true intellectual might well be considered a person who has not yet found a respectable occupation in the community or to use a contradiction in terms, a "specialist in general ideas", interested in pursuing a universal truth that by definition cannot be found and, if by any stroke of good luck it is found, it is not susceptible of any socially useful practical application.

In this sense, perhaps, the French semiologist Romand Barthes (in Le grain de la voix, Seuil, Paris) had defined the intellectual as nothing but a mere "residue", a débris, 
something not quite essential for the society. And yet, one cannot forget that as soon as a political regime is turned into a more or less violent dictatorship or even a benevolent despotism, these "residues", that is to say the free, not specialized, uncommitted, dissenting intellectuals come to be regarded as "dangerous elements" of the community, "corrosive critics", as the Nazis would have it, of the existing order and of the general climate of opinion to the point of thinking that they deserve to be exiled, if not physically eliminated.

Hence, the notion of the engagement, or commitment of the intellectual. This notion has found one of its most vocal proponents in Jean-Paul Sartre. During the second half of the twentieth century this notion has been weighing very heavily on all intellectuals, especially on the European ones, as it becomes perfectly clear nor only from the One dimensional Man by Herbert Marcuse, soon to become the livre de chévet of all the members of the student movement of 1968, but also from the "Manifesto des intellectuels", published by Sartre in the volume Eighth of his Situations - Autour de '68 (Gallimard, Paris, 1972, esp. pp. 372-476). It is perhaps suggestive to recall that the "Cultural programme" by Sőren Kierkegaard came out in 1846, just two years before the Manifesto by Marx and Engels, published in Brussels in 1848, to be repeated, at least as regards the title, a century later by Sartre.

But, commitment for what? In Marx and Engels the goal was explicit. In Sartre the goal is as enthusiastically proclaimed as its nature remains elusive. The idea of Sartre's commitment reveals the basic uncertainties of present day "general" intellectual. For Sartre, the commitment is for freedom. But here we have a "petitio principii": freedom is born out of the commitment; on the other hand, commitment is at the service of freedom. One may ask: what kind of freedom is Sartre writing about? What are its sources? Its goals, and, therefore, the foundation of its ethical obligation? Sartre leaves the question open. Nobody could specify the reasons or the goals to which one should commit himself. There is no way to establish general moral rules. Existence comes before essence. This means that the starting point of any philosophical reflection is not man in general, but man in a given, specific situation, historically bound and objectively conditioned. Thus, the split between theory and praxis is overcome, but it seems evident that the solution of the split is purely verbal, that is proclaimed rather than theoretically grounded.

In this connection, and contrary to his premises, the overall tone of Sartre turns dogmatic: "Man is nothing else but what he is doing. This is the principle of existentialism. This is also what is called subjectivity and what we are reprimanded for. But what do we want to say when we state that man has a greater dignity than the stone or the table? We want to say that first of all man exists, that is to say that man is first of all a being that throws himself towards a future and that he is aware of this project for the future" (L'homme n'est rien d'autre que ce qu'il se fait. Tel est le premier 
principe de l'existentialisme. C'est aussi ce qu'on appelle la subjectivité et que l'on nous reproche sous ce nom même. Mais que voulons nous dire par la, si non que t'homme a une plus grande dignité que la pierre au la table? Car nous voulons dire que l'homme existe d'abord, c'est a dire que l'homme est d'abord ce que se jette vers un avenir et ce qui est conscient de ce projet dans l'avenir ${ }^{3}$ ).

Needless to say, Sartre's conception of the intellectual as the last all-dimensional artisan in a modern, technically advanced society, based on division of labour, can only claim the role of a more or less radical critic of society and in this sense, in Sartre's view, he goes well beyond and is, at any rate, essentially different from the intellectual as a technician. In Sartre's terms, the technician can hardly be regarded as an intellectual in the proper sense. In fact, far from indulging into speculations as regards universal philosophical problems, he relies on a narrow-gauged skill or competence. He is undoubtedly a person well versed in a specific field of learning or definite production activity and as such he can legitimately be regarded as a person who uses his or her intellect professionally.

A tentative typology of intellectuals in modern society could probably include the following types:

1. the inventors or creators of ideas, considered as having a vast and lasting influence, sufficient to characterize an entire historical epoch;

2. creators of ideas, differently identified as humanists and scientists on the basis of their specific orientation towards philosophy, history, literature and in general the sciences of culture in which consciousness seems to prevail over factual certainty and empirical validation:

a) scientists in the strict sense of the term, as researchers and scholars active in the field of "natural sciences", also labeled as "exact sciences", such as physics, biology, chemistry, and so on.

b) Two fields of learning have been respectively defined as "soft sciences" and "hard sciences", a distinction especially expounded by C.P. Snow 4 in order to show that humanistic disciplines are not really scientific but rather can be termed as the sciences of "vagueness" whereas natural sciences would be, in his opinion, the sciences of absolute certainty. Recent developments in scientific thought, however, point to the fact that all sciences are highly problematic and that problem-awareness is at their very source ${ }^{5}$. A mediation between the "two cultures" (humanistic and scientific) has been proposed by Wolf Lepenies with a "third culture", acting like a bridge between humanistic

\footnotetext{
${ }^{3}$ Cfr. Jean-Paul Sartre, L 'existentialisme est un humanisme, Nagel, Paris, 1946, pp. 22-31

${ }^{4}$ Cfr. C.P. Snow, The Two Cultures and the Scientific Revolution, London and New York, 1960

${ }^{5} \mathrm{Cfr}$, in this connection Ilyia Prigogine, Isabelle Stengers, The New Alliance
} 
studies and scientific research. This third culture should be, according to Lepenies, sociology;

3. Teachers and vulgarizers, who perform the essential task of popularizing and propagating major intellectual results and scientific achievements in the school system and the mass media, both printed and audio-visual.

Apparently, in a technically advanced modern society, "intellectual" professions are going to bypass the repetitive, relatively unskilled jobs. This does not mean that the number of intellectuals is bound to increase tremendously. An example would perhaps clarify my point. Of two successful lawyers who have won their case and celebrate while waiting for their "fat" fees, the one who is not only a competent jurist but an intellectual also, keeps asking himself questions such as: "I have won. Fine. But, are the existing laws on the basis of which I was able to convince the jury really reflecting the need for justice that is present in the society at large? Are these laws fully compatible with the moral feeling of the community or are they, for some important aspect, lagging behind?" Far from being completely satisfied with his legal victory, this successful lawyer questions not the formal but the substantive adequacy of the legal system. Thus he keeps the critical spirit alive and deserves to be considered not only a competent technician or expert in legal matters, but an intellectual. 